\title{
Radiopacity and cytotoxicity of Portland cement associated with niobium oxide micro and nanoparticles
}

\author{
Leticia Boldrin MESTIERI', Mário TANOMARU-FILHO', Ana Livia GOMES-CORNÉLIO', Loise Pedrosa SALLES', \\ Maria Inês Basso BERNARDI ${ }^{2}$, Juliane Maria GUERREIRO-TANOMARU'
}

\author{
1- Department of Restorative Dentistry, Araraquara Dental School, Univ. Estadual Paulista - UNESP, Araraquara, São Paulo, SP, Brazil. \\ 2- Institute of Physics, University of São Paulo, São Carlos, SP, Brazil.
}

Corresponding address: Mario Tanomaru-Filho - Rua Humaitá, 1680 - PO BOX 331 - Centro - Araraquara - SP - Brazil - 14801-903 - Phone +55-16-33016390 - Fax. +55-16-3301-6392 - e-mail: tanomaru@uol.com.br

Submitted: May 27, 2014 - Modification: August 12, 2014 - Accepted: September 3, 2014

\section{ABSTRACT}

\begin{abstract}
bjective: Mineral Trioxide Aggregate (MTA) is composed of Portland Cement (PC) and bismuth oxide (BO). Replacing BO for niobium oxide ( $\mathrm{NbO}$ ) microparticles ( $\mathrm{Nb \mu}$ ) or nanoparticles ( $\mathrm{Nb \eta}$ ) may improve radiopacity and bioactivity. The aim of this study was to evaluate the radiopacity and cytotoxicity of the materials: 1) PC; 2) White MTA; 3) PC+30\% $\mathrm{Nb} \mu$; 4) $\mathrm{PC}+30 \% \mathrm{Nb \eta}$. Material and Methods: For the radiopacity test, specimens of the different materials were radiographed along an aluminum step-wedge. For cell culture assays, Saos-2 osteoblastic-cells (ATCC HTB-85) were used. Cell viability was evaluated through MTT assay, and bioactivity was assessed by alkaline phosphatase activity assay. Results: The results demonstrated higher radiopacity for MTA, followed by $\mathrm{Nb} \mu$ and Nbn, which had similar values. Cell culture analysis showed that PC and PC+NbO associations promoted greater cell viability than MTA. Conclusions: It was concluded that the combination of $\mathrm{PC}+\mathrm{NbO}$ is a potential alternative for composition of MTA.
\end{abstract}

Keywords: Silicate cement. Niobium. Nanotechnology.

\section{NTRODUCTION}

Mineral Trioxide Aggregate (MTA) is indicated for retrograde filling due to its favorable physicochemical and biological properties ${ }^{24}$. Considering that the main component of MTA is Portland Cement (PC), several studies have demonstrated that these two materials present similar properties ${ }^{5}$. Bismuth oxide (BO), the radiopacifying agent in MTA, interferes negatively with MTA properties by increasing its porosity and, consequently, lowering its resistance ${ }^{6}$. For this reason, new radiopacifying agents have been evaluated as alternatives to $\mathrm{BO}$; as niobium oxide, a metal which is commonly combined with titanium for endosseous implants that displays excellent biocompatibility and mechanical resistance and is impervious to corrosion and disintegration ${ }^{16,21}$. More recently, niobium oxide ( $\mathrm{NbO}$ ) has been evaluated as a radiopacifying agent for dental cements ${ }^{27}$. Several authors have studied the ability of this metal to form apatite crystals when coming in contact with body fluids ${ }^{11}$, as well as the in vitro behavior of niobium-containing alloys ${ }^{28}$.

MTA in contact with osteoblastic cells (MG-63) provided cell adhesion and proliferation ${ }^{2}$, and induced collagen formation in the culture ${ }^{23}$. When the same cell line was cultured on the surface of a niobium-containing titanium alloy, rapid cell growth associated with greater alkaline phosphatase (ALP) activity and high levels of osterix, osteocalcin, and bone sialoprotein gene expression were observed ${ }^{26}$. Similar results for ALP activity in rat osteoblastic cells (MC3T3-E1) were also reported ${ }^{18}$, concluding that niobium is capable of stimulating proliferation and differentiation of osteoblastic cells.

Since PC-based materials present potential applications in Dentistry, the aim of this study was to evaluate the radiopacity, cytotoxicity, and bioactivity of PC combined with $\mathrm{NbO}$ micro and nanoparticles as alternatives to $\mathrm{BO}$ as a radiopacifying agent. 


\section{MATERI AL AND METHODS}

For analysis of the different materials' properties, the following groups were established: 1) PC (CPB40 Estrutural Votoran, Votorantim Cimentos, São Paulo, SP, Brazil); 2) MTA Angelus (Angelus, Londrina, PR, Brazil); 3) PC+30\% NbO microparticles ( $\mathrm{Nb \mu}$ ) (CBMM, Companhia Brasileira de Metalurgia e Mineração, Araxá, MG, Brazil); 4) PC+30\% NbO nanoparticles (Nbq).

To obtain the $\mathrm{Nb \eta}$, the polymeric precursor method was used, at the Physics Institute of São Carlos (University of São Paulo, São Carlos, SP, Brazil). An aqueous solution of ammonium niobium oxalate (CBMM, Companhia Brasileira de Metalurgia e Mineração, Araxá, MG, Brazil) was prepared, and ammonium hydroxide was added to form a precipitate of niobium hydroxide. This was filtered and washed to eliminate the oxalate ions, and then dissolved in an aqueous citric acid solution. The niobium content present in the solution was determined by gravimetric analysis, and the solution was maintained under agitation at $70^{\circ} \mathrm{C}$ for $2 \mathrm{~h}$ for reaction. Ethylene glycol was added in the ratio of $60: 40$, and the solution was maintained heated and under agitation. This solution was heated to $300^{\circ} \mathrm{C}$ in an electric oven for $4 \mathrm{~h}$, and the resultant mass was ground and calcinated in an electric oven to $700^{\circ} \mathrm{C}$ on aluminum plates for $2 \mathrm{~h}-127$. All cements were prepared according to the proportions mentioned in Figure 1.

\section{Radiopacity}

To evaluate the radiopacity, standardized specimens measuring $10 \mathrm{~mm}$ in diameter by $1 \mathrm{~mm}$ in thickness were positioned on occlusal radiographic films (Insight, Kodak Comp, Rochester, NY, USA) and radiographed along with an aluminum step-wedge, presenting variable thickness of 2-mm increments (from 2 to $16 \mathrm{~mm}$, Figure 2). The radiograph images were digitized using a desktop scanner (SnapScan 1236, Agfa, Munich, Germany), and the density of the different sample areas were expressed in millimeter of $\mathrm{Al}$ in accordance to the aluminum step-wedge using the ImageTool software (Image Tool for Windows version 3.0, San Antonio, TX, USA $)^{25}$. Statistical analysis was performed by ANOVA and Tukey's parametric tests ( $n=5$ areas/ group).

\section{Cell culture}

Osteoblastic cells derived from human osteosarcoma (Saos-2, ATCC HTB-85) were grown as monolayer cultures in T-75 flasks (Costar, Corning Incorporated, Corning, NY, USA) containing Dulbecco's Modified Eagle Medium (DMEM, Gibco, Glasgow, UK) supplemented with $10 \%$ fetal bovine serum (FBS, Gibco, Glasgow, UK) and 1\% solution of penicillin and streptomycin (PenStrep, Gibco, Glasgow, UK) at $37^{\circ} \mathrm{C}, 5 \% \mathrm{CO}_{2}$, and $95 \%$ humidity. After confluence, the cells were detached by trypsin/ethylenediaminetetraacetic acid mixture (Trypsin-EDTA solution - 0.25\%, Sigma-Aldrich, St. Louis, MO, USA) for 2 minutes, centrifuged in 15 mL Falcon tubes (Costar, Corning Incorporated, Corning, NY, USA), and plated on 24-well plates (TPP - Techno Plastic Products, Zollstrasse, Trasadingen, Switzerland) for further assays at a density of $2 \times 10^{4}$ cells per well ( $n=3$ wells/material).

\section{Cements extracts}

The powder of each test material was weighed, and $1 \mathrm{~g}$ was placed at the bottom of $50 \mathrm{~mL}$ Falcon tube (Costar, Corning Incorporated, Corning, NY, USA) and exposed to UV light for 15 minutes to prevent bacterial contamination. Each tube containing the different materials received $10 \mathrm{~mL}$ of DMEM medium and was incubated for 4 hours at $37^{\circ} \mathrm{C}$ and $95 \%$ humidity. Thereafter, the samples were centrifuged to remove the debris and to obtain clear stock solutions of fresh cement extracts (ratio of $1 \mathrm{~g}$ cement: $10 \mathrm{~mL}$ of DMEM). The stock solutions were diluted in DMEM and three elute concentrations were prepared for the cell viability assays: $50 \mathrm{mg} / \mathrm{mL}, 10 \mathrm{mg} / \mathrm{mL}$, and $2 \mathrm{mg} / \mathrm{mL}^{10}$.

\section{Cell viability assay ( MTT)}

To assess the cell viability rate, the Saos- 2 were

\begin{tabular}{|c|c|c|c|}
\hline Group & Material & $\begin{array}{c}\text { Proportion } \\
\text { (cement : distilled } \\
\text { water) }\end{array}$ & Manufacturer \\
\hline $\mathrm{CP}$ & White Portland Cement & $1 \mathrm{~g}: 320 \mu \mathrm{L}$ & $\begin{array}{c}\text { Votoran, Votorantin Cimentos, Rio Branco do } \\
\text { Sul, PR, Brazil }\end{array}$ \\
\hline MTA & White Mineral Trioxide Aggregate & $1 \mathrm{~g}: 320 \mu \mathrm{L}$ & Angelus, Londrina, PR, Brazil \\
\hline Nb $\mu$ & $\begin{array}{c}\text { PC }(70 \%)+30 \% \text { microparticulated } \\
\text { niobium oxide }\end{array}$ & $1 \mathrm{~g}: 400 \mu \mathrm{L}$ & $\begin{array}{c}\text { Institute of Physics, University of São Paulo- } \\
\text { USP, São Carlos, SP, Brazil }\end{array}$ \\
\hline Nbn & $\begin{array}{c}\text { PC }(70 \%)+30 \% \text { nanoparticulated } \\
\text { niobium oxide }\end{array}$ & $1 \mathrm{~g}: 400 \mu \mathrm{L}$ & $\begin{array}{c}\text { Institute of Physics, University of São Paulo- } \\
\text { USP, São Carlos, SP, Brazil }\end{array}$ \\
\hline
\end{tabular}

Figure 1- Experimental materials evaluated and proportions used 
exposed to the experimental material extracts for the periods of 1,3 , and 7 days. The cells exposed to the culture medium were the positive control of viability (CT). After the incubation periods, the medium was changed to $900 \mu \mathrm{L}$ of DMEM medium without FBS and $100 \mu \mathrm{L}$ of MTT solution ( $5 \mathrm{mg} /$ $\mathrm{mL}$ of MTT Formazan, Sigma-Aldrich, St. Louis, MO, USA). The culture plates were incubated for an additional $4 \mathrm{~h}$ at $37^{\circ} \mathrm{C}, 5 \%$ of $\mathrm{CO}_{2}$, and $95 \%$ humidity. After that, the MTT solution was washed and the crystals formed at the bottom of the culture plates were solubilized in $500 \mu \mathrm{L}$ acid isopropyl alcohol ( $\mathrm{HCl}$; isopropyl alcohol, 0.04N). Samples containing $100 \mu \mathrm{L}$ were transferred to 96-well plates (TPP - Techno Plastic Products, Zollstrasse, Trasadingen, Switzerland) and analyzed in an automatic microplate reader (VersaMax ELISA Microplate Reader, Molecular Devices, Sunnyvale, CA, USA) set to an optical density of $570 \mathrm{~nm}^{22}$. The experiment was repeated three times independently and the obtained data were analyzed by ANOVA and Tukey's-HSD post-hoc test (level of significance: $\mathrm{p} \leq 0.05)$.

\section{ALP activity assay}

After incubation with cement extracts at $10 \mathrm{mg} /$ $\mathrm{mL}$ for the periods of 1,3 , and 7 days (concentration of choice according to MTT results), the cells were washed with $1 \mathrm{~mL}$ of phosphate-buffered saline (PBS 1X, Gibco, Glasgow, UK) and $1 \mathrm{~mL}$ of sodium lauryl sulfate solution ( $0.1 \%$ SDS, Sigma-Aldrich, St. Louis, MO, USA) was added to each well, followed by incubation for 30 minutes at room temperature. Subsequently, $50 \mu$ were transferred to single tubes for ALP assay using a kit (Labtest,
Lagoa Santa, MG, Brazil). The absorbance was read at $590 \mathrm{~nm}$ in a spectrophotometer (600 Plus, Femto, São Paulo, SP, Brazil) ${ }^{20}$. The experiment was repeated three times independently and the data obtained were subjected to Kruskal-Wallis non-parametric test and to pairwise comparisons by Dunn's method (level of significance: $p \leq 0.05$ ).

\section{Statistical analysis}

All data were presented as mean and standard deviation of the mean. The results were analyzed with the software program GraphPad Prism 5 (GraphPad Software Inc., San Diego, CA, USA).

\section{RESULTS}

\section{Radiopacity evaluation}

The results presented in Table 1 demonstrate greater mean radiopacity for MTA Angelus (A) followed by $\mathrm{Nb} \mu$ and $\mathrm{Nb \eta}$, which did not differ statistically from each other (B).

\section{Cell viability assay ( MTT)}

In general, all the test groups presented similar pattern of cell viability according to the days of exposure when compared to each other (Figure 3). When compared to control (CT) at day 1, all the groups of cells exposed to the different material extracts presented significant low viability rate in a concentration-dependent manner. The MTA group at $50 \mathrm{mg} / \mathrm{mL}$ presented the lowest cell viability rate at days 1 and 3 of cell exposure. The elute concentration of $50 \mathrm{mg} / \mathrm{mL}$ presented the lowest cell viability rate when compared to CT. Interestingly, the results revealed an increase at the

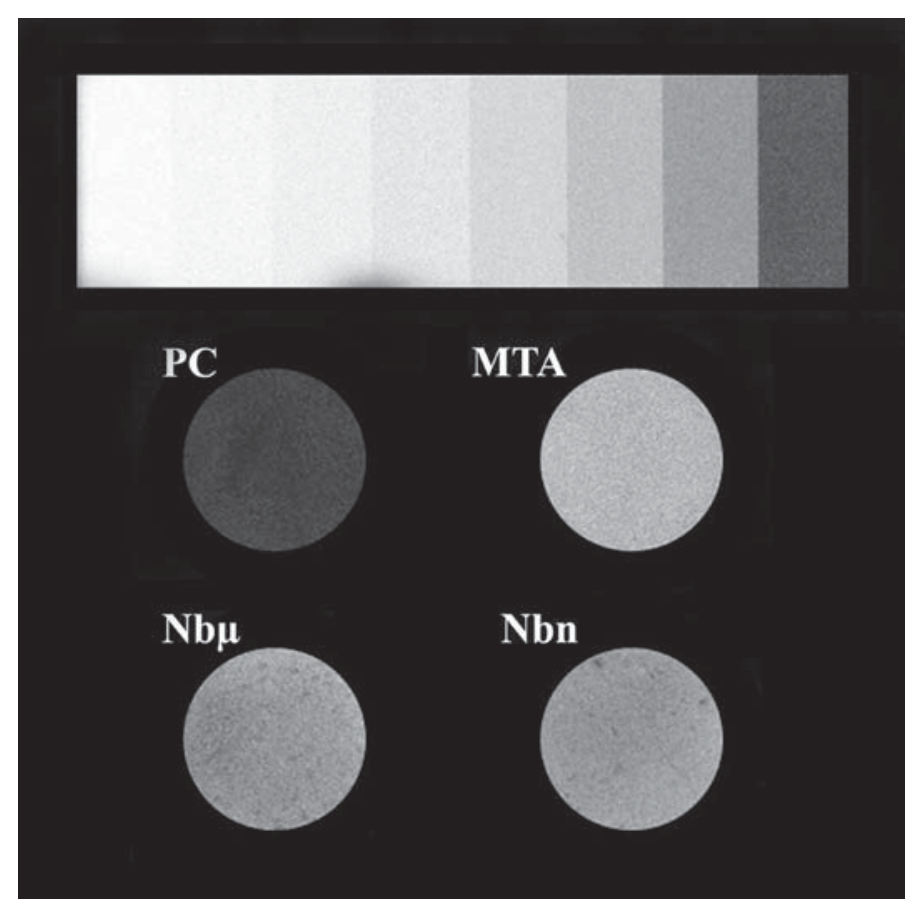

Figure 2- Radiograph showing the specimens made of different materials alongside the aluminum step-wedge 
Table 1- Radiopacity mean values (mm Al) of the evaluated materials. Equal letters represent no statistical difference $(p>0.05)$

\begin{tabular}{|c|c|}
\hline Material & Radiopacity (mm Al) \\
\hline PC & $1.145^{\mathrm{C}}$ \\
\hline MTA & $5.018^{A}$ \\
\hline $\mathrm{Nb \mu}$ & $3.371^{B}$ \\
\hline $\mathrm{Nb \eta}$ & $3.701^{B}$ \\
\hline
\end{tabular}

cell viability in a time-dependent manner, achieving a rate similar to CT at 3 and 7 days of exposure to extracts at the concentrations of $2 \mathrm{mg} / \mathrm{mL}$ and 10 $\mathrm{mg} / \mathrm{mL}$, with the exception of Saos-2 exposed to $10 \mathrm{mg} / \mathrm{mL}$ of MTA at day 3 .

\section{ALP activity assay}

After $24 \mathrm{~h}$ of incubation, the greatest ALP activity was observed for $\mathrm{Nbn}$ and PC $(p>0.05)$, followed by MTA Angelus and $\mathrm{Nb \mu}$. At $72 \mathrm{~h}$, there was no statistical difference among the groups $(p>0.05)$. At 7 days, PC and $\mathrm{Nb} \mu$ differed statistically from MTA Angelus and $\mathrm{Nb \eta}$, which were statistically similar

\section{MTT Assay}

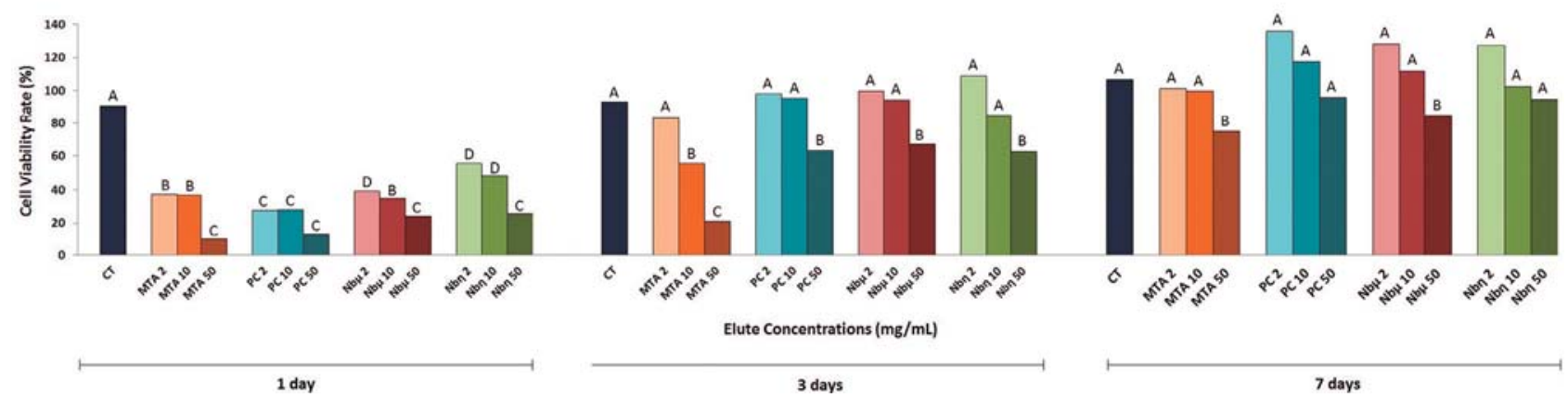

Figure 3- Viability rate of Saos-2 exposed to test cement extracts. Image of percentage charts representing the results obtained with three independent experiments for each group is shown. Cells without any elute treatment, control group (CT). MTA Angelus cement elute (MTA 2, 10 and 50), Portland cement (PC 2, 10, and 50), PC+30\% NbO microparticles $(\mathrm{Nb} \mu 2,10$, and 50$), \mathrm{PC}+30 \% \mathrm{NbO}$ nanoparticles ( $\mathrm{Nb \eta} 2,10$, and 50) cell treatment groups at concentrations of 2, 10, and $50 \mathrm{mg} / \mathrm{mL}$, respectively. Different letters represent significant differences between all cement elute treatments and control group in each time of exposure. ANOVA, Tukey's-HSD post-hoc test $(p<0.05)$

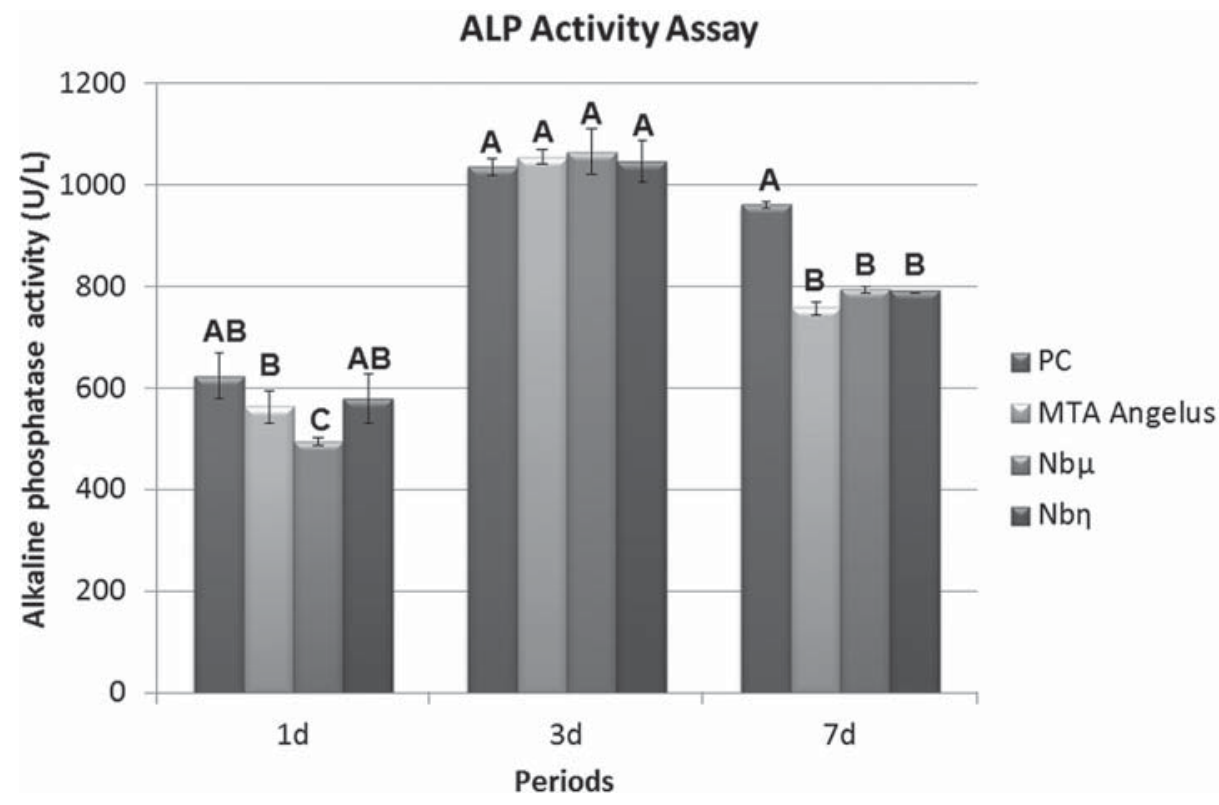

Figure 4- ALP activity assay of Saos-2 exposed to test cement extracts. MTA Angelus cement (MTA Angelus), Portland cement (PC 2), PC $+30 \% \mathrm{NbO}$ microparticles $(\mathrm{Nb} \mu), \mathrm{PC}+30 \% \mathrm{NbO}$ nanoparticles ( $\mathrm{Nb \eta}$ ) cell treatment groups at concentration of $10 \mathrm{mg} / \mathrm{mL}$. Different letters represent significant differences between all cement elute treatments and control group in each time of exposure Kruskal-Wallis, Dunn's method ( $p>0.05$ ) 
to each other $(p>0.05)$ (Figure 4).

\section{DISCUSSION}

Since bismuth oxide (BO) interferes negatively in MTA, NbO may represent an alternative to replace it. In the present study, the results from the radiopacity assays demonstrated that addition of NbO micro and nanoparticles to MTA Angelus resulted in similar radiopacity values, above 3.0 mm Al. The ISO 6876/2001 standards ${ }^{13}$ established that endodontic filling materials should present radiopacity of at least $3.0 \mathrm{~mm} \mathrm{Al}$. According to ANSI/ADA ${ }^{1}$, endodontic cements should be at least $2.0 \mathrm{~mm} \mathrm{Al}$ more radiopaque than dentin or bone. Therefore, all the materials evaluated in this study, except for PC, presented radiopacity above the values recommended by ANSI/ADA and are in accordance with ISO 6876/2001.

In regards to biological responses in vitro, cell viability and bioactivity tests are important to assess the cell damage and the biological action potential of various materials. For this purpose, we used the Saos- 2 osteoblastic cell line. These cells allow evaluation of long-term effects in the differentiation of osteoblasts such as ability to deposit the extracellular matrix for mineralization, which is an adequate means to assess the formation of mineralization modules induced by exposure to different cements ${ }^{19}$.

The cell viability assay (MTT) showed lower results for the cements and MTA Angelus after 24 $\mathrm{h}$ when compared to the control. This is probably due to rapid $\mathrm{pH}$ changes, which initially may acted as an aggression against the cells ${ }^{17}$. However, at concentrations of $2 \mathrm{mg} / \mathrm{mL}$ and $10 \mathrm{mg} / \mathrm{mL}$, the materials presented viability equal or above that of the control, which is a response similar or better than that of MTA Angelus, increasing the percent of viable cells during days. From 3 days, all groups have similar to control. These results are in accordance with other study ${ }^{10}$, in which the cytotoxicity of different radiopacifying agents combined with PC at the same concentrations were evaluated.

The MTT results lead to the selection of $10 \mathrm{mg} /$ $\mathrm{mL}$ as the appropriate concentration to evaluate the bioactivity by ALP assay. This test demonstrated that $\mathrm{Nb} \mu$ and Nbn stimulated Saos-2 producing ALP similar to MTA Angelus in $72 \mathrm{~h}$ and similar to $\mathrm{Nbn}$ in 7 days. The $\mathrm{Nb \mu}$ was better than MTA Angelus in 7 days, confirming the mineralization potential which is fundamental for bone formation. The ALP activity induced by PC and MTA on the Saos- 2 cells was previously studied ${ }^{8}$, and the results demonstrated that PC and MTA can induce mineralization in this cell line. Saos- 2 has also been used to evaluate the mineralization potential and ALP activity promoted by hydroapatite-based materials ${ }^{4,12}$, which are recommended as biomaterials to induce bone regeneration.

The satisfactory results for ALP activity in the cells exposed to cements containing niobium micro and nanoparticles may be related to the effect of niobium on mineralization and bioactivity ${ }^{15}$. Studies about the interaction of MC3T3-E1 osteoblastic cells with niobium clearly showed the formation of a superficial layer of calcium phosphate due to niobium alkalinization, which may favor the repair process of hard tissues ${ }^{9}$. Furthermore, in vivo analysis of $\mathrm{NbO}$ demonstrated no changes on hematological and leukocytes cells, and decreased cytotoxicity during the evaluated periods ${ }^{7}$.

The methods proposed in this study are in vitro models, which are simple, reproducible, and costeffective assays, indicated to evaluate the biological properties of endodontic sealers. In vivo testing should be performed after obtaining a favorable response on in vitro assays ${ }^{14}$. However, in vitro evaluation can give us an overview of the biological effects of the materials, suggesting outcomes to in vivo studies ${ }^{3}$.

\section{CONCLUSI ON}

The results demonstrate that replacement of $\mathrm{BO}$ with $\mathrm{NbO}$ is viable, based on radiopacity, cell viability, and bioactivity assays. However, further studies are required in order to evaluate other mechanical and biological properties of $\mathrm{NbO}$ and to achieve better understanding of this radiopacifying agent.

\section{ACKNOWLEDGEMENTS}

To São Paulo Research Foundation (FAPESP 2011/18239-4) for funding this research and Prof. Dr. Carlos Rossa Júnior for his collaboration.

\section{REFERENCES}

1- American National Standards Institute/American Dental Association. Specification No. 57 for endodontic sealing materials. Chicago: ANSI/ADA; 2000.

2- Attik GN, Villat C, Hallay F, Pradelle-Plasse N, Bonnet H, Moreau $\mathrm{K}$, et al. In vitro biocompatibility of a dentine substitute cement on human MG63 osteoblasts cells: Biodentine ${ }^{\mathrm{TM}}$ versus MTA ${ }^{\circledR}$. Int Endod J. 2014 Feb 12. Epub ahead of print.

3- Azar NG, Heidari M, Bahrami ZS, Shokri F. In vitro cytotoxicity of a new epoxy resin root canal sealer. J Endod. 2000;26:462-5. 4- Bernhardt A, Dittrich R, Lode A, Despang F, Gelinsky M. Nanocrystalline spherical hydroxyapatite granules for bone repair: in vitro evaluation with osteoblast-like cells and osteoclasts. ] Mater Sci Mater Med. 2013;24:1755-66.

5- Bramante CM, Kato MM, Assis GF, Duarte MA, Bernardineli N, Moraes IG, et al. Biocompatibility and setting time of CPM-MTA and white Portland cement clinker with or without calcium sulfate. J Appl Oral Sci. 2013;21:32-6. 
6- Coomaraswamy KS, Lumley PJ, Hofmann MP. Effect of bismuth oxide radioopacifier content on the material properties of an endodontic Portland cement-based (MTA-like) system. J Endod. 2007;33:295-8.

7- Dsouki NA, Lima MP, Corazzini R, Gáscon TM, Azzalis LA, Junqueira VB, et al. Cytotoxic, hematologic and histologic effects of niobium pentoxide in Swiss mice. J Mater Sci Mater Med. 2014;25:1301-5.

8- Gandolfi MG, Perut F, Ciapetti G, Mongiorgi R, Prati C. New Portland cement-based materials for endodontics mixed with articaine solution: a study of cellular response. J Endod. 2008;34:39-44.

9- Godley R, Starosvetsky D, Gotman I. Corrosion behavior of a low modulus beta-Ti-45\%Nb alloy for use in medical implants. J Mater Sci Mater Med. 2006;17:63-7.

10- Gomes-Cornélio AL, Salles LP, Campos da Paz M, Cirelli JA, Guerreiro-Tanomaru JM, Tanomaru-Filho M. Cytotoxicity of Portland cement with different radiopacifying agents: a cell death study. J Endod. 2011;37:203-10.

11- Gostin PF, Helth A, Voss A, Sueptitz R, Calin M, Eckert J, et al. Surface treatment, corrosion behavior, and apatite-forming ability of Ti-45Nb implant alloy. J Biomed Mater Res B Appl Biomater. 2013;101:269-78.

12- Gustavsson J, Ginebra MP, Planell J, Engel E. Osteoblast-like cellular response to dynamic changes in the ionic extracellular environment produced by calcium-deficient hydroxyapatite. J Mater Sci Mater Med. 2012;23:2509-20.

13- International Organization for Standardization. ISO 6876 - Dentistry: Root canal sealing materials. Geneva: ISO; 2001. 14- Koulaouzidou EA, Economides N, Beltes P, Geromichalos G, Papazisis K. In vitro evaluation of the cytotoxicity of ProRoot MTA and MTA Angelus. J Oral Sci. 2008;50:397-402.

15- Kushwaha M, Pan X, Holloway JA, Denry IL. Differentiation of human mesenchymal stem cells on niobium-doped fluorapatite glass-ceramics. Dent Mater. 2012;28:252-60.

16- McMahon RE, Ma J, Verkhoturov SV, Munoz-Pinto D, Karaman I, Rubitschek F, et al. A comparative study of the cytotoxicity and corrosion resistance of nickel-titanium and titanium-niobium shape memory alloys. Acta Biomater. 2012;8:2863-70.

17- Naghavi N, Ghoddusi J, Sadeghnia HR, Asadpour E, Asgary S. Genotoxicity and cytotoxicity of mineral trioxide aggregate and calcium enriched mixture cements on L929 mouse fibroblast cells. Dent Mater J. 2014;33:64-9.
18- Obata A, Takahashi Y, Miyajima T, Ueda K, Narushima T, Kasuga $\mathrm{T}$. Effects of niobium ions released from calcium phosphate invert glasses containing $\mathrm{Nb}_{2} \mathrm{O}_{5}$ on osteoblast-like cell functions. ACS Appl Mater Interfaces. 2012;4:5684-90.

19- Pérard M, Le Clerc J, Watrin T, Meary F, Pérez F, Tricot-Doleux $S$, et al. Spheroid model study comparing the biocompatibility of Biodentine and MTA. J Mater Sci Mater Med. 2013;24:1527-34. 20- Rosa AL, Beloti MM. Development of the osteoblast phenotype of serial cell subcultures from human bone marrow. Braz Dent J. 2005; 16:225-30.

21- Rosalbino F, Macciò D, Scavino G, Saccone A. In vitro corrosion behaviour of Ti-Nb-Sn shape memory alloys in Ringer's physiological solution. J Mater Sci Mater Med. 2012;23:865-71. 22- Salles LP, Gomes-Cornélio AL, Guimarães FC, Herrera BS, Bao SN, Rossa-Junior C, et al. Mineral trioxide aggregate-based endodontic sealer stimulates hydroxyapatite nucleation in human osteoblast-like cell culture. J Endod. 2012;38:971-6.

23- Silva EJ, Herrera DR, Rosa TP, Duque TM, Jacinto RC, Gomes BP, et al. Evaluation of cytotoxicity, antimicrobial activity and physicochemical properties of a calcium aluminate-based endodontic material. J Appl Oral Sci. 2014;22:61-7.

24- Tanomaru-Filho M, Jorge EG, Guerreiro-Tanomaru JM, Gonçalves M. Radiopacity evaluation of new root canal filling materials by digitalization of images. J Endod. 2007;33:249-51. 25- Tanomaru-Filho M, Silva GF, Duarte MA, Gonçalves M, Tanomaru JM. Radiopacity evaluation of root end filling materials by digitization of images. J Appl Oral Sci. 2008;16:376-9.

26- Vandrovcova M, Jirka I, Novotna K, Lisa V, Frank O, Kolska $Z$, et al. Interaction of human osteoblast-like Saos-2 and MG-63 cells with thermally oxidized surfaces of a titanium-niobium alloy. PLoS One. 2014; 9:e100475.

27- Viapiana R, Flumignan DL, Guerreiro-Tanomaru JM, Camilleri J, Tanomaru-Filho M. Physicochemical and mechanical properties of zirconium oxide and niobium oxide modified Portland cementbased experimental endodontic sealers. Int Endod J. 2014;47:43748.

28- Xiong J, Li Y, Hodgson PD, Wen C. In vitro osteoblast-like cell proliferation on nano-hydroxyapatite coatings with different morphologies on a titanium-niobium shape memory alloy. J Biomed Mater Res A. 2010;95:766-73. 